\title{
A morte de deus e a ascenção do homem: uma análise da religião judaico-cristã moderna a partir da obra de José Saramago
}

Francisca Carolina Lima da Silva ${ }^{1}$

http://lattes.cnpq.br/6018595380586301

Enviado em: 15/09/2018

Aceito em: 12/12/2019

Resumo: Uma das temáticas predominantes na obra de José Saramago é a releitura e a intertextualidade com as escrituras sagradas que compõem os evangelhos do judaísmo-cristão. Essa prática se constrói a partir de uma desconstrução das narrativas bíblicas e de uma leitura subversiva de alguns dos preceitos que fundaram o ideário ocidental. Ateu convicto, nessas inversões antirreligiosas, Saramago, ao mesmo tempo em que questiona crenças inabaláveis, apresenta-nos a desmistificação da História oficial, a partir de uma visão humanizadora dos episódios bíblicos. Dentro desse diálogo, uma das principais subversões que o autor realiza é a inversão de papéis entre Deus e o homem: enquanto este, através da figura de Jesus Cristo, assume as funções sagradas de Deus, (principalmente a de ser a medida de todas as coisas), aquele corporifica qualidades tipicamente humanas, comprovando, para o autor, sua ineficiência enquanto entidade superior. Este artigo propõe supor que Saramago materializa a perspectiva do Cristianismo moderno em sua obra, através da adoção da ideia filosófica da morte cultural de Deus, por meio da humanização e do desvendamento do caráter cruel e sanguinário dessa personagem. Para tanto, faremos uso dos postulados da Literatura Comparada para proceder nossa análise, utilizando também os conceitos que definem a paródia. Nosso cotejamento se dá acerca da estrutura de composição dos textos bíblicos e da possibilidade de tratamento de tais escritos sob uma perspectiva literária.

Palavras-chave: Cristianismo moderno; Ficção; Transgressão; Humanização.

Abstract: One of the predominant themes in the work of José Saramago is the interpretation and the intertextuality with the sacred scripture which compound the gospels of Christian-Judaism. This practice is built on the desconstruction of biblical narratives and a subversive reading of some of the principles that founded Western ideas. Confirmed atheist, at such religious inversions, Saramago, while questioning unshakable beliefs, presents us with the demystification of official history, from a human view of biblical episodes. In this dialogue, one of the main subversions that the author performs is the reversal of roles between God and man: while the latter, through the figure of Jesus Christ, assumes the sacred functions of God, (especially that of being the measure of all things), the first embodies typical human qualities, confirming, for the author, its inefficiency as a Superior being. This article aims to suppose that Saramago materializes the perspective of modern Christianity in his work, through the adoption of the philosophical idea of the cultural death of God, through the humanization and the unveiling of the cruel and sanguinary nature of this character. To do so, we will use the terms of Comparative Literature to carry out our analysis, also using concepts that define parody. Our comparison is about the structure of the biblical texts, and the possibility of treating such writings from a literary perspective.

Key words: Modern Christianity; Fiction; Transgression; Humanization.

\footnotetext{
${ }^{1}$ Graduada em letras e especialista em literatura brasileira e africana pela Universidade Regional do Cariri, mestre em Literatura Comparada pela Universidade Federal do Ceará, atua como professora temporária na Universidade Regional do Cariri, na área de teoria da literatura e literaturas africanas de expressão portuguesa. E-mail: carolinalima.cs@hotmail.com
} 


\section{1 - INTRODUÇÃO}

Saramago é um autor que utiliza a literatura para refletir sobre a realidade, por meio de um processo de ficcionalização de dados reais e verossímeis, mesclados com uma inventividade ímpar. Ele parte da concretude para a imanência num movimento que pretende repensar o presente através, principalmente, do passado. Este método compósito está presente na maioria de suas obras, em especial nos romances. Atrelado a isso, e como suporte, ele faz uso da intertextualidade para chegar a tal finalidade.

Um dos exemplos desse trabalho com a realidade é a releitura dos textos sagrados do judaísmo-cristão, enquanto alicerces principais da construção do ideário cultural ocidental. Essa é uma problemática que inquieta o lusitano de tal forma, que chegou a dedicar duas obras ao tema, a saber: O Evangelho segundo Jesus Cristo (1991) e Caim (2009). O resultado a que chega Saramago, ao fazer uso dos textos base de tais religiões, é exatamente relativizar seus discursos, cristalizados pelo tempo e pelo dogmatismo aurático relacionado a eles.

Através do uso da paródia Saramago compõe sua versão ficcional dos textos bíblicos, utilizando informações e dados oriundos desses textos, mas repensados e reorganizados na narrativa, de forma completamente dessacralizada.

Historicamente, o Cristianismo, percebendo a necessidade de se moldar à nova realidade construída pelo homem moderno, transforma-se, no intuito de permanecer vivo e atuante. É sobre esse dado que Saramago vai impetrar sua crítica. Assim, observamos, através da materialização de seu pensamento nas obras em estudo que, para ele, o Cristianismo usou a figura humana de Jesus Cristo que vê no humanismo de Cristo a possibilidade de sua redenção. O Deus, juiz e vingativo do Antigo Testamento, já não é coerente com o perfil desse novo homem. Destarte, a religiosidade cristã moderna substitui Deus por Jesus, através da teoria da encarnação.

Nesse sentido, nosso estudo propõe supor que Saramago materializa essa perspectiva do Cristianismo moderno em sua obra, através da adoção da ideia filosófica da morte cultural de Deus. A ideia de divindade renascerá em Jesus Cristo, enquanto homem, potencializando assim um pensamento de teor antropológico, em que o homem passa a ser a medida de todas as coisas ${ }^{2}$, ocupando, inclusive, o lugar de Deus no âmbito da religião Cristã.

Para alcançar tal objetivo, utilizaremos os pressupostos da Literatura Comparada, que nos permite construir um diálogo entre as obras e as teorias filosóficas a respeito da morte de Deus, assim como fazer uso de dados históricos e literários para redimensionar a leitura realizada pelo autor em sua obra.

\section{2- IN NOMINE HOMO: O ADVENTO DO HOMEM NO EVANGELHO DE SARAMAGO}

Saramago compartilha da definição de religião enquanto criação da mente humana e que, ao ser legitimada, ganha existência própria e autônoma. Isso se aplica consequentemente, aos objetos materiais e não materiais produzidos pela religião como instrumentos de instauração e manutenção dos dogmas e preceitos que a sustentam, como é o caso dos

\footnotetext{
${ }^{2}$ Frase criada por Protágoras, antigo filósofo grego, em que supõe que nada devia ter valor absoluto, visto que a verdade pode ser relativizada conforme as tendências e preferências predominantes em determinadas sociedades, culturas e mesmo períodos. Assim, tal expressão resume o espírito subjetivista e relativista da modernidade.
}

https://periodicos.unifap.br/index.php/letras Macapá, v. 8, n. 3, $2^{\circ}$ sem., 2018 
textos bíblicos, no que concernem às religiões de base judaico-cristã. Neles foi aplicada, no decorrer da história, uma interpretação de base teológica vinculada ao seu sentido sagrado e legitimada enquanto verdade suprema, apesar das lacunas e incoerências que fogem ao sentido de realidade e de verossimilhança.

Temos, portanto, a desconsideração de todos os elementos literários constitutivos de tais escritos na interpretação cristalizada pela Igreja. Essa abordagem do texto bíblico é fundamentada a partir da categorização do Cristianismo como uma religião histórica, "cujos dogmas primordiais se baseiam em acontecimentos" (BLOCH, 2001, p. 58). Saramago, então,

realiza uma crítica aos textos tidos como verdade, como os da Bíblia. Por meio de um fato histórico - o bíblico - Saramago força o leitor a repensar o passado histórico da bíblia, ao ler sua ficção [...]. Agindo assim, Saramago muda o olhar dos leitores, que passam a questionar a veracidade do texto sagrado tal como ele chega ao homem hoje, e percebem que ficção e história se equivalem enquanto construções narrativas (SYLVESTRE, 2011, p. 47).

O autor relativiza em sua obra a visão religiosa dos textos considerados sagrados pelo judaísmo-cristão, na tentativa de revelar aquilo que fora silenciado, colocado à margem. Com isso, questiona a veracidade dos acontecimentos referidos, tendo em vista as narrativas bíblicas não serem imunes à influência ideológica daqueles que a compuseram.

Apesar de o Cristianismo ser uma religião histórica, baseada na existência concreta de um Messias e sua ação no mundo, não se pode, cientificamente, desvincular o caráter histórico dos textos bíblicos de seu aspecto sagrado e imanente. É na convergência desses dois fatores que Saramago vem propor sua reflexão, no intuito de desenvolver o diálogo a respeito da manutenção da religiosidade de base judaico-cristã em fundamentos considerados históricos e comprováveis, quando na verdade estão embebidas de uma ficção tendenciosa, que visa a validar o caráter sagrado atribuído a tais textos.

Saramago faz uso da abertura que a literatura tem em relação ao compromisso com a verdade tão almejada pelos historiadores para compor seu enredo, baseado naquilo que poderia ser, e não no que foi. A literatura cumpre aqui o papel de preencher as lacunas deixadas pela história, no sentido de propor uma reflexão do presente através do rememoramento de suas origens, desmistificando fatos e símbolos da história do ocidente.

Para tanto, os narradores saramaguianos buscam na presença do passado, como reelaboração crítica do presente, o artifício para pautar a tendência das releituras da história, da religiosidade e dos mitos realizadas pelo autor, concretizado por meio da inversão do tempo cronológico da história, por um tempo entrecruzado, indefinido.

Partindo da premissa de que o texto literário pode possuir diferentes significados, a partir da leitura dele em diferentes tempos, acreditamos que a compreensão da existência de valores que devem ser seguidos e instituídos como modelo de conduta moral são relativos e arbitrários. Sendo assim, a recepção de tais valores imbuídos na obra são redimensionados de acordo com a co-variação do tempo histórico de sua composição, acrescido ao tempo em que o episódio fonte se localiza, adicionado ainda ao momento de sua leitura, culminando assim na ressignificação do mito ou do fato histórico, de acordo com essa configuração do tempo.

No que diz respeito à desconstrução dos mitos feita pelo autor, daqueles que compõem o ideário cultural do homem e também dos que competem ao compêndio da tradição judaicocristã, devemos considerar que, 
para Saramago, bem como para os escritores que adotam uma perspectiva "pós-moderna", o mito não passa de linguagem convencionalmente aceita por uma tradição para explicar algumas "verdades" que fundamentam determinada cultura, então, o papel do escritor, ao retomá-los seria refletir a respeito dos jogos de poder que alimentam a tradição dos mitos (SYLVESTRE, 2011, p. 35).

De tal modo, destacamos que o mito se vale da crença; logo, não pode ser comprovado cientificamente, ou mesmo empiricamente. Ele vem materializar o inconsciente, explicar e justificar os aspectos imanentes da existência humana, tendo em vista a impossibilidade de o homem conviver com a dúvida e com sua inadequação a alguns aspectos do mundo, principalmente no nível imanente, criando assim entidades maiores e mais poderosas para justificar essas questões incompatíveis com a realidade concreta e comprovável. Essa feição do mito contribuiu para a elaboração e justificação do surgimento e desenvolvimento das religiões mais variadas nos dias atuais.

A multiplicidade de formas de manifestação religiosa surge da premissa das crenças e da fé no inefável adequarem-se às necessidades e angústias dos homens, que modernamente degustam uma experiência cada vez mais particular de sua cultura, validada pelo fenômeno da fragmentação do homem moderno. Porém, acerca dessa pluralidade do mito, Cassirer defende: "os sujeitos do mito e os atos rituais são de uma variedade infinita, porém os motivos do pensamento mítico e da imaginação mítica são sempre os mesmos" (CASSIRER, 1976, p. 53). A unidade que justifica o pensamento mítico estaria relacionada, portanto, ao medo do inexplicável, que por sua vez estaria diretamente ligado à noção do sagrado.

Aos poucos, a sacralidade vinculada ao mito vem sendo desconstruída, ao passo que as pesquisas atuais procuram investigar a origem e a justificativa da permanência deles, principalmente os religiosos, intentando o fato de que "ainda atuam na psique das pessoas, dominando o imaginário delas, embora tenham sua origem em tempos bastante remotos" (SYLVESTRE, 2011, p. 19). Essa proposição justifica a insistência de Saramago em trazer à tona a discussão acerca dos sustentáculos nos quais as religiões de tradição judaico-cristã foram construídas, interrogarando a verossimilhança e a posição sagrada destinada aos mitos.

Mesmo pretendendo questionar tais mitos, Saramago não foge de seu campo de atuação literária, mantendo-se fiel ao aspecto ficcional que o fazer literário lhe permite. A literatura, mesmo sem fugir da referência do real, cria um universo seu, imune a leis e códigos pautados na realidade e na lógica, continuando, mesmo assim, a funcionar como crítica ou negação do real. É, portanto, no limite do simbólico que a literatura de Saramago atua, principalmente aquela que dialoga com os textos bíblicos e históricos, na busca do desvendamento das verdades escondidas por eles.

Para analisarmos a materialização da religiosidade moderna em Saramago, utilizaremos uma de suas obras mais discutidas, O Evangelho segundo Jesus Cristo (1998), responsável por pautar a construção de uma parcela do ideário cultural ocidental, através dos textos que compõem o Novo Testamento, assim como de sua leitura teológica.

Nos dias atuais a conjuntura dogmática e organizacional, mantida pelas igrejas de base judaico-cristã, encontra dificuldade em adequar-se à nova visão do homem e sua maneira de relacionar-se com o mundo moderno e pós-moderno. Assim, ao retomar o texto bíblico, o autor reflete a propósito do desmantelamento da estrutura ética e moral da sociedade contemporânea, pois questiona seus princípios fundadores, tendo em vista que "a religião, o mito, e a arte assumem um papel fundamental, ao lado do conhecimento teórico- 
científico, de propiciar ao mundo uma interpretação de si mesmo. [...] Uma forma própria de entender o mundo que a própria modernidade produziu" (MAGALHÃES, 2000, p. 133).

A substituição da verdade "universal" por diversas outras verdades textuais caracteriza as leituras feitas por Saramago a respeito de alguns episódios considerados sagrados. O método utilizado pelo autor para realizar tal propósito é a paródia, que consiste na releitura de um texto, adotando uma postura de transgressão e oportunizando uma nova interpretação dele. Conforme Kothe:

Paródia, segundo o étimo, significa “canto paralelo": é um texto que contém outro texto em si, do qual ela é uma negação, uma rejeição e uma alternativa. Ela geralmente diz que o outro texto deixou de dizer e ela insiste no fato de não ter sido dito. A paródia é um texto duplo, pois contém o texto parodiado e, ao mesmo tempo, a negação dele. Ela é, portanto, a síntese de uma contradição, dando prioridade para a antítese, em detrimento da tese proposta pelo texto parodiado. [...] A paródia procura liquidar pelo ridículo o papel do texto parodiado. Sempre surge como resposta à institucionalização sacralizadora de um texto (KOTHE, 1980, p. 98).

Saramago é, portanto, um irremediável parodiador dos textos fundadores de ideários culturais, sejam eles histórico-patrióticos ou religiosos, fazendo uso da palavra literária para desmistificar a versão/leitura oficial desses fatos.

O autor, ao parodiar os textos sobre os quais se baseia para compor seus evangelhos, realiza um cruzamento dos planos mítico e ficcional, no intuito de desfazer todo e qualquer discurso de manipulação, cabendo ao narrador esse papel questionador das verdades absolutas, pois ele está sempre relacionado a um processo de tentativa de desalienação indireta do leitor, ao fazê-lo refletir acerca dos fatos que expõe e, principalmente, sobre a forma subversiva como narra tais fatos. O texto paródico vem, então, fundar uma nova realidade, comprometida com a verdade múltipla, oriunda da configuração plural da sociedade e do pensamento humano.

Após comentarmos brevemente as releituras míticas realizadas por Saramago, partiremos para a análise a que pretendemos, que será pautada, por sua vez, na apreciação da personagem principal do romance: "Jesus".

Inicialmente, para compreendermos o Jesus saramaguiano é necessário fazer um passeio pelas informações acerca de sua vida que ficaram fora dos escritos canônicos. Revelações essas que serviram como subsídio para o autor, já que ele emprega em suas obras uma aprofundada pesquisa histórica, no sentido de compor suas releituras de forma coerente, para que assim tenha a prerrogativa de questionar os fatos que usa como base de seus escritos. Com isso, Saramago pretende delinear um caráter humano e histórico do Messias do Cristianismo.

Partindo da premissa de que Jesus Cristo comprovadamente existiu, conforme esclarece Zuurmond:

Com razão hoje em dia não se discute mais se Jesus realmente existiu. No início da 'era cristã' viveu na Palestina um judeu, Jesus de Nazaré, que de alguma maneira desempenhou papel decisivo na origem do que depois seria chamado 'o caminho (messiânico)' e mais tarde ainda 'a Igreja cristã' (ZUURMOND, 1994, p. 18).

Temos, por conseguinte, a primeira e mais contundente justificativa para a construção intertextual do Jesus de Saramago, desenvolvida a partir de uma mescla de informações das mais variadas áreas: mítica, histórica, apócrifa, etc. Isso é potencializado pelo fato de a 
personagem, por natureza, já ser dotado, desde os textos canônicos, de diversas perspectivas que o relacionam a sua humanidade, de acordo com a visão e a estilística de cada evangelista.

Faz-se necessário considerar a forma como o autor se apropria desses textos para compor seu Evangelho. Para tanto, é importante lembrar a forma como os escritos bíblicos foram formados, considerando também aquilo que ficou à margem da Bíblia, em seu Novo Testamento, além da composição e a apresentação formal dele.

O Novo Testamento é mesclado por evangelhos, escritos em forma de parábolas, logo, são textos que pretendem passar uma lição de sabedoria, doutrinando assim seus leitores. Esses escritos foram compostos em épocas, lugares e por autores diferentes, formando o que se denomina de "canôn bíblico". Na ocasião da composição do livro sagrado, muitos outros textos foram candidatados a arranjar o Novo Testamento, porém, a administração eclesiástica promoveu uma "seleção" dos escritos que fariam parte da obra.

Essa escolha foi diretamente condicionada, pois foram escolhidos aqueles textos que dialogavam e validavam a linha das narrativas contidas no Antigo Testamento. Os textos excluídos na seleção formaram o que se conhece hoje como evangelhos e textos apócrifos. Portanto, nada que fosse contra essa vertente, e que oportunizasse o questionamento da sacralidade das personagens bíblicos, foi selecionado. Assim, a Igreja Católica exercia a função de mediadora entre o céu e a terra.

Para compor seu Jesus, Saramago bebe principalmente das fontes heréticas, já que elas desvendam um perfil da personagem pouco conhecido, e validam, assim, o caráter humano da personagem saramaguiana.

Partindo para a análise da humanização da personagem Jesus em Saramago, destacamos de início, sua insistência em transformar o meio social no qual estava inserido.

Muitos pesquisadores defendem um engajamento de Jesus na questão da reação contra o domínio romano, que perdurava no contexto na época, acrescentando, assim, um caráter revolucionário ao nazareno. A respeito disso, Arias defende que Jesus foi um "judeu inconformista que rompeu muitos tabus de seu tempo e foi condenado à morte na cruz pelo simples pecado de ter provocado, com suas utopias libertárias, os grandes poderes da sua época: o religioso e o político" (ARIAS, 2001, p. 11). A questão do domínio de Roma também incomoda o Jesus de Saramago, como nos é possível perceber nesse diálogo que o nazareno trava com um dos escribas do templo, quando ainda adolescente:

O Senhor consente que as nossas espadas não se levantem contra a força que nos está oprimindo, que cem dos nossos não ousem atrever-se contra cinco dos deles, que dez mil judeus tenham de encolher-se diante de cem romanos, Estás no Templo do Senhor e não num campo de batalha, O Senhor é o deus dos exércitos, Mas, lembra-te, o Senhor impôs as suas condições, Quais, Se cumprirdes as minhas leis, se guardardes os meus preceitos, disse o Senhor, Que leis não cumprimos e que preceitos não guardámos para que tenhamos de aceitar por justa e necessária, como castigo de pecados, a dominação de Roma, O Senhor o saberá, Sim, o Senhor o saberá, quantas vezes o homem peca sem saber, mas explica-me por que se serve o Senhor do poder de Roma para castigar-nos, em vez de o fazer directamente, cara a cara com aqueles a quem elegeu para seu povo, O Senhor conhece os seus fins, o Senhor escolhe os seus meios, Queres então dizer que é vontade do Senhor que os romanos mandem em Israel, Sim, Se é como dizes, temos de concluir que os rebeldes que andam a lutar contra os romanos estão também a lutar contra o Senhor e a sua vontade, Concluis mal, E tu contradizes-te, escriba, O querer de Deus pode ser um não querer, o seu não querer a sua vontade (SARAMAGO, 2005, p. 171-172). 
Nessa passagem percebemos o tom de inconformidade de Jesus em relação à questão exposta, assim como sua insatisfação com os desígnios e a justiça divina. A partir desse fragmento, Jesus começa a questionar Deus, pois passa a refletir sobre as ações praticadas ou autorizadas por ele, tendo em vista, como esclarece o escriba na passagem acima, ele ser o administrador do universo, e nada acontecer sem que ele o saiba ou autorize. Nesse episódio, Jesus dialoga no intuito de compreender a vontade de Deus em permitir a dominação romana sobre o povo Judeu, mas a conclusão a que chega é a de que ele parece não se importar com o povo nomeado como seu, ou seria mesmo o povo judeu o rebanho de Deus? Entretanto, mesmo que aparente, o Jesus de Saramago não é revolucionário, no sentido político da palavra. Seu Jesus é, afinal, um humanista radical.

Porém, o fato de Jesus pregar o amor e a misericórdia já o levava a romper com o sistema estabelecido, haja vista a forte opressão que o povo judeu sofria sob o jugo romano, o que nos leva, novamente, ao Jesus inconformista:

Mas uma coisa é certa: Jesus não foi um homem da ordem, do sistema, conservador do status quo. Quanto a isso não há a menor dúvida, e a Igreja nunca deveria tê-las alimentado. O profeta de Nazaré sempre foi um inconformista, um homem de ruptura do sistema estabelecido (ARIAS, 2001, p. 193).

Sua revolução era muito mais religiosa do que social, porém, uma coisa não desvincula a outra. Jesus se opunha a muitos dos dogmas judaicos que feriam o princípio de liberdade do homem.

Ao passo que se posiciona contra alguns dos preceitos judaicos, Jesus oportuniza uma visão mais democrática e revolucionária dessa religiosidade, baseada no homem:

Sua revolução não se baseava nas armas, na força bruta, e nem sequer na mudança para uma sociedade mais democrática, aberta e justa. O que Jesus propôs foi uma revolução a partir dos fundamentos mesmos do ser humano. A religião - a de seu tempo e a de todos os tempos -, com sua imagem de um deus vingativo e justiceiro, era a que escravizava os homens e atava as consciências, a que atemorizava e justificava a desigualdade social. Pois bem, Jesus veio propor a grande revolução de um Deus que fez o sol nascer para os justos e pecadores, que não faz distinção entre homens e mulheres, entre fiéis e infiéis, entre puros e impuros, pois, como já anunciara o profeta Isaías, mesmo que uma mãe, no auge da loucura, do desespero ou da maldade possa abandonar um filho, Deus nunca o fará. É a certeza suprema desse amor, que é maior que o mundo (ARIAS, 2001, p. 196).

A missão de Jesus consistia, portanto, em moldar o judaísmo de forma a adequar-se às necessidades de seu povo, o que não demonstra uma revolução absoluta. Ao passo que Jesus questionava o judaísmo arcaico, deflagrava determinados posicionamentos de inconformidade em relação ao poder da alta esfera religiosa a respeito do domínio romano. Para Jesus, a cúpula judia não só reconhecia a legitimidade da autoridade de Roma sobre seu povo, como também auxiliava na manutenção de seu poder absoluto, uma vez que usufruía dele. Esse aspecto de Jesus é permutado para o nazareno saramaguiano, que revela seu repúdio em relação a esses preceitos, por exemplo, quando se recusa a comer a carne advinda de um sacrifício a Deus:

Pastor entende fazer a sua ceia, que Jesus já disse que não comerá duma carne a que, sem querer, tirou a vida. Para a religião que cultiva e os costumes a que obedece, estes escrúpulos de Jesus são subversivos, haja vista a matança desses outros inocentes todos os dias sacrificados

https://periodicos.unifap.br/index.php/letras

Macapá, v. 8, n. 3, $2^{\circ}$ sem., 2018 
nos altares do Senhor, maiormente em Jerusalém (SARAMAGO, 2005, p. 138).

Aqui, o narrador destaca os motivos que levam Jesus a recusar a refeição, reafirmando o papel de protagonista do homem, em detrimento da onipotência divina, pregando sua libertação dos procedimentos que confrontavam a verdadeira fé, desvinculada de qualquer moeda de troca ofertada pela misericórdia divina.

Esse amor incondicional pelo homem, demonstrado por Jesus, é incorporado no romance de Saramago, que desvela o perfil humano passível de erro, de prazer e até mesmo de medo de um homem que se submeteu aos acrifício pelos outros, mesmo que em seu íntimo desejasse fugir de tal destino.

O percurso de Jesus pelo romance atesta esse aspecto humanista, que é construído conforme o protagonista toma consciência de seu destino. O próprio nazareno a defende em diversas passagens da obra, como nesta, em que dialoga com Maria de Magdala sobre seu relacionamento sexual com ela:

Deus não deveria privar de nenhum dos frutos da sua obra as mulheres de que também foi autor, Conhecer homem, por exemplo, Sim, como tu vieste a conhecer mulher, e mais não devias precisar, sendo, como és, o filho de Deus, Quem contigo se deita não é o filho de Deus, mas o filho de José (SARAMAGO, 2005, p. 345).

Mais adiante, na narrativa, o judeu da Galileia afirma: "Que não te surpreenda ver que o filho de Deus é um filho de homem”" (SARAMAGO, 2005, p. 347).

Todos os passos de Jesus no Evangelho de Saramago, guiados ou não por seu pai divino, levamno a seu reconhecimento como filho de Deus, e, por mais que Jesus acredite em algumas ocasiões estar vivendo segundo seu livre-arbítrio, em suas palavras finais, através de sua descoberta, somos surpreendidos com o fato de que todo o seu percurso foi direcionado para uma única função: conseguir aumentar potencialmente o número de seguidores de seu pai, no intuito de expandir o exercício de sua adoração, marcando, assim, o aspecto egoísta e egocêntrico de Deus, conforme é possível evidenciar na seguinte passagem:

E qual foi o papel que me destinaste no teu plano, O de mártir, meu filho, o de vítima, que é o que de melhor há para fazer espalhar uma crença e afervorar uma fé. As duas palavras, mártir, vítima, saíram da boca de Deus como se a língua que dentro tinha fosse de leite e mel [...] o Diabo o olhava com uma expressão enigmática, misto de interesse científico e involuntária piedade. [...], E a minha morte, será como, A um mártir convém-lhe uma morte dolorosa, e se possível infame, para que a atitude dos crentes se torne mais facilmente sensível, apaixonada, emotiva, Não estejas com rodeios, diz-me que morte será a minha, Dolorosa, infame, na cruz (SARAMAGO, 2005, p. 213).

Por via dessa revelação de Deus percebemos Jesus ocupando a função do cordeiro que fora obrigado a ofertar no deserto, já que aceita sacrificar-se não aos homens, mas a Deus, funcionando como uma metáfora da humanidade e dedicando esse holocausto para acalmar os ânimos divinos, como é-nos possível perceber nesta passagem da obra:

Jesus morre, morre, e já o vai deixando a vida, quando de súbito o céu por cima da sua cabeça se abre de par em par e Deus aparece, vestido como estivera na barca, e a sua voz ressoa por toda a terra, dizendo, Tu és o meu Filho muito amado, em ti pus toda a minha complacência. Então Jesus compreendeu que viera trazido ao engano como se leva o cordeiro ao sacrifício, que a sua vida fora traçada para morrer assim desde o princípio dos princípios, e, subindo-lhe à lembrança o rio de sangue e de sofrimento que do seu lado irá nascer e alagar toda a terra, clamou para o céu aberto onde Deus sorria, Homens, perdoai-lhe, porque ele não sabe o que 
fez (SARAMAGO, 2005, p. 374).

Neste trecho apreendemos o fato de Jesus ter consciência da irracionalidade do ato de seu pai, que, através do sangue e da morte, convence o homem da necessidade de adoração a sua figura, demarcando o poder de Deus a partir do medo e do castigo. Essa leitura de Saramago funciona como crítica aos postulados da religiosidade de base judaico-cristã, que fundou e mantém um domínio no mundo baseado exatamente nesses dois pressupostos: o medo e o castigo. Para o autor, isso se configura, no mínimo, como arbitrário, já que o Cristianismo afirma serem o bem e a compaixão seus sustentáculos.

De fato, para Jesus não há escapatória, seu destino de mártir irá se cumprir. Porém, este Jesus humanista subverte seu sacrifício ou, pelo menos, o tenta, ao declarar-se rei dos judeus, na ocasião de seu julgamento e morte, demonstrando mais uma vez sua predileção pelos homens, em detrimento de Deus:

Que mentiras, perguntou Jesus, Uma, a de seres o rei dos Judeus, Eu sou o rei dos Judeus, A outra, a de seres o filho de Deus, Quem te disse que eu digo que sou o filho de Deus, Todos por aí, Não lhes dês ouvidos, eu sou o rei dos Judeus, Então, confessas que não és o filho de Deus, Repito que sou o rei dos Judeus, Tem cuidado, olha que só essa mentira basta para que sejas condenado, O que disse, disse (SARAMAGO, 2005, p. 370).

Este desejo é manifesto no Evangelho de Saramago na tentativa do protagonista em desvincular a vontade de seu pai divino como geradora de sua morte, por meio de sua declaração a respeito dos motivos pelos quais é condenado à execução. Enquanto nos textos sagrados Jesus "[n] unca falou contra o governo romano - exatamente o contrário -, e se criticava a liderança judaica era apenas em termos espirituais” (JONHSON, 2001, p. 123), em Saramago os acontecimentos que o levam à morte são invertidos, pois, como dissemos, o próprio Jesus declara-se rei dos judeus, posição essa que o complica politicamente, uma vez que naquela época os judeus viviam sob o jugo de Roma.

O narrador de Saramago manipula esse fato para determinar a morte de Jesus enquanto homem, condenado por tentar usurpar o poder de Herodes, em seu representante Pilatos, governador romano que possuía legitimidade em governar a região de Jerusalém, como nos é possível perceber na seguinte passagem da obra:

O filho de Deus deverá morrer na cruz para que assim se cumpra a vontade do Pai, mas, se no lugar dele puséssemos um simples homem, já não poderia Deus sacrificar o Filho, Queres pôr um homem no teu lugar, um de nós, perguntou Pedro, Não, eu é que irei ocupar o lugar do Filho, Em nome de Deus, explica-te, Um simples homem, sim, mas um homem que se tivesse proclamado a si mesmo rei dos Judeus, que andasse a levantar o povo para derrubar Herodes do trono e expulsar da terra os romanos, isto é o que vos peço, que corra um de vós ao Templo a dizer que eu sou esse homem, e talvez que, se a justiça for rápida, não tenha a de Deus tempo de emendar a dos homens (SARAMAGO, 2005, p. 367).

Jesus acredita ter fugido de seu destino de filho de Deus, enganando seu pai: "Lançaram também a Jesus uma corda aos pés para que não pudesse fugir, e Jesus disse consigo mesmo, porque assim o cria, Tarde chega, eu já fugi”" (SARAMAGO, 2004, p. 368). Posteriormente, conforme arquitetado, Jesus proclama-se rei dos judeus, mesmo diante do governador romano, em ocasião de seu julgamento:

Que dizes tu que és, perguntou o procurador, Digo o que sou, o rei dos Judeus, E que é que 
pretende o rei dos Judeus que tu dizes ser, Tudo o que é próprio de um rei, Por exemplo, Governar o seu povo e protegê-lo, Protegê-lo de quê, De tudo quanto esteja contra ele, Protegê-lo de quem, De todos quantos contra ele estejam, Se bem compreendo, protegê-lo-ias de Roma, Compreendeste bem, E para o protegeres atacarias os romanos, Não há outra maneira, E expulsar-nos-ias destas terras, Uma coisa leva à outra, evidentemente, Portanto, és inimigo de César, Sou o rei dos Judeus, Confessa que és inimigo de César, Sou o rei dos Judeus, e a minha boca não se abrirá para dizer outra palavra (SARAMAGO, 2005, p. 372).

Assim, não há escapatória, visto que o nazareno é condenado à morte, porém a escolha da forma pela qual se dará seu sacrifício chama a atenção dos pesquisadores e estudiosos, pois "Jesus foi punido com a morte [...] com a crucificação, [destinada] aos sediciosos políticos" (ARIAS, 2001, p. 61). A maneira como Jesus morre gera ambigüidade, pois, os crimes religiosos eram punidos com a morte por apedrejamento. Logo, Saramago faz uso desse dado histórico para destacar mais uma vez a humanidade de Jesus, ao morrer como rei dos judeus e não por ser filho de Deus.

Quando Jesus resolve sacrificar-se pelos homens, e não por Deus, ele passa definitivamente para o lado do homem. Assim, pelo menos em parte, o Nazareno tem a falsa sensação de exercer seu livre-arbítrio, certeza essa que será desfeita quando percebe que não havia outro caminho que pudesse trilhar, destacando o perfil do Jesus do Cristianismo. A análise de Franco Crespi acerca da morte de Jesus, pautada no pensamento de Vitiello, dialoga com o aspecto da morte do nazareno descrita por Saramago, já que ele acredita que

a morte de Cristo na cruz daria justamente testemunho da impossibilidade de redenção da finitude. O grito "Meu Deus, meu Deus, por que me abandonastes?" exprime para Vitiello, o conteúdo essencial da mensagem de Cristo: "é a voz mais verdadeira do Filho do homem, a voz do abandonado, da solidão extrema, do deserto do mundo do qual o Pai se ausentou. [...] Tal subtração do Pai ao Filho no Filho é a dor extrema da finitude - que é tal somente pela experiência da infinita ausência do infinito". (VITIELLO, 1995, p. 67) Com base nesse pressuposto, Vitiello acha que a interpretação da paixão e morte de Cristo como sacrifício necessário para libertar a humanidade da culpa e da violência "seja a mais grave mistificação realizada pelo Cristianismo histórico; uma leitura regressiva que trai a mensagem cristã" (CRESPI, 1999, p. 54).

Essa é a perspectiva adotada por Saramago a respeito da morte de Cristo, já que seu narrador não descreve a caminhada e a aceitação de Jesus ao seu sacrifício de forma amena e compassiva; pelo contrário, o filho de José questiona e até tenta persuadir Deus a mudar de ideia a respeito disso. Assim, o autor chama a atenção para o fato de a sacralização da morte de Jesus tratar-se de uma mitificação de sua figura, uma vez que o transcendentalismo acrescentado à cena sacrifical é de responsabilidade da Igreja:

Assim, o que inicialmente fora colocado como um convite libertador para a escuta do mistério divino e para a resposta pessoal à vida do Cristo, enquanto revelação de um Deus que renuncia ao próprio poder para assumir inteiramente a existência terrena na sua precariedade e incerteza, sofrendo e morrendo na cruz, transformou-se, por um lado, em um juízo culpabilizante e, por outro lado, na exaltação triunfalista de uma libertação do tempo, que acaba reduzindo a vida terrena à simples prova, a um momento de transição para uma conciliação suprema que será concretizada no além (CRESPI, 1999, p. 17).

Essa leitura da Igreja a respeito das simbologias em torno da morte de Cristo é desconsiderada por Saramago, já que em seu Evangelho não é narrada sua ressurreição, o que destaca, mais uma vez, o caráter humano de seu Jesus. 
Com razão, a pregação de Cristo, como vimos, pode ser interpretada como "a origem daquele processo de dessacralização que, finalmente, encontrou pleno desenvolvimento em nossa época" (CRESPI, 1999, p. 70). O texto de Saramago, apesar de ficcional, materializa essa dessacralização, uma vez que não só questiona o perfil de Jesus, como constrói um novo, longe de qualquer dogmatismo, pois ele "abriu-se para a ofuscante evidência de ser o homem um simples joguete nas mãos de Deus, eternamente sujeito a só fazer o que a Deus aprouver, quer quando julga obedecerlhe em tudo, quer quando em tudo supõe contrariá-lo" (SARAMAGO, 2005, p. 181).

\section{3 - SARAMAgO E A MORTE DE DEUS: UMA RELAÇÃO PROFANA}

]Mesmo considerando os textos saramaguianos no âmbito literário, a partir de sua própria materialidade, não é possível desconsiderar o diálogo deles com o universo extra literário, neste caso, o religioso. Como nos referimos, a forma como o autor relê os textos bíblicos materializa em sua obra alguns dos conceitos defendidos por teólogos e filósofos a respeito do Cristianismo do século XX e XXI, após ser repensado para se adaptar aos tempos modernos e contemporâneos. Esse redimensionamento perpassa, principalmente, pela teoria da encarnação, que equipara o homem a Deus, emancipando-o. É exatamente isso o que faz Saramago, como nos foi possível perceber através das análises realizadas até aqui.

Para que Jesus Cristo, a figura humana central do Cristianismo, pudesse ascender como encarnação de Deus foi necessário que ele morresse. A possibilidade da morte de Deus vem sendo tema recorrente nos debates acerca da nova configuração do Cristianismo, em parâmetros filosóficos, evidentemente. Essa possibilidade surgiu a partir da ideia central desenvolvida por Dietrich Bonhoeffer da "Teologia da morte de Deus" ou "Ateísmo Cristão", que defende basicamente a secularização da mensagem de Cristo para que ela possa adaptarse ao homem moderno, trazendo uma interpretação mais aberta e desvinculada do sentido religioso aos textos que compõem o cânon bíblico.

A evolução da técnica e da ciência trouxe importantes descobertas que invalidaram muito do dogmatismo institucional da Igreja, a partir do desenvolvimento de um ateísmo que nega a necessidade da participação da religião na manutenção de sua vida, levando assim o homem moderno a não só negar, mas também hostilizar Deus, impedindo-o de reconciliar-se com sua suposta bondade e poder. Essa forma de religiosidade desenvolveuse com o intuito de aproximar o Cristianismo ao pensamento do homem moderno, conforme pontua Charles Bent:

Frequentemente no passado os homens confundiram os fins da ciência com os da religião. [...] Mas a ciência seguiu a sua própria lógica e o seu próprio desenvolvimento interno e, gradualmente, começou a encarar o seu papel como uma tentativa de compreensão do próprio mundo fenomenológico, em vez de tentar decifrar a inteligibilidade de Deus no mundo. [...] Este novo conceito é ateísta e humanista. No século XIX o Cristianismo tornou-se menos misterioso, menos religioso, menos exigente e mais culto à medida que mais pensadores e teólogos cristãos abraçavam o conceito de um mundo coerente consigo próprio, Deus começou a ser considerado cada vez mais, como um intruso (BENT, 1968, p. 61-62).

É exatamente essa perspectiva que encontramos em Saramago, através da personagem Jesus Cristo, ao rejeitar sua sacralidade quando cede à sua humanidade. Para sermos mais claros, faremos agora um breve resumo do pensamento central do Movimento da Morte de Deus, comparando seus conceitos à retratação feita por Saramago da religião de base 
judaico-cristã em suas releituras.

O Movimento da Morte de Deus almejava, basicamente, um Cristianismo sem religião, desligado de qualquer conceito teocêntrico e onipotente de Deus. Os teólogos do movimento defendem que vivenciamos a imposição de uma nova era, uma era de desesperança, descrença e alienação, a era marcada pela morte da fé, pelo fim do Cristianismo, pela morte de Deus.

Paralelamente ao Movimento da Morte de Deus, é possível constatar uma considerável transformação de atitudes em todos os campos da atividade humana. Isso interfere diretamente na concepção religiosa dos povos, causando o desligamento do homem da necessidade de uma divindade para lhes ordenar e lhes explicar a existência humana. Portanto, o indivíduo contemporâneo procura agora tomar coragem para aceitar o imutável e o inevitável. Assim, para Vahanian "o homem ocidental rompeu com toda a sujeição a uma concepção mundial cristã e entrou agora numa nova era cultural, caracterizada por uma concepção mundial radicalmente imanentista. $\mathrm{O}$ homem moderno vive agora numa era póscristã" (VAHANIAN apud BENT, 1968, p.8).

No contexto do mundo moderno, portanto, "concepções do homem e do mundo, que são fundamentalmente imanentistas, científicas e seculares substituíram os pontos de vista que eram transcendentais, mitológicos e sacro-sacramentais" (VAHANIAN apud BENT, 1968, p. 18). Entretanto, é importante destacar que essa perspectiva de mundo, peculiar ao homem moderno, não figura como verdade para todos eles, já que o mundo é insatisfatório, pois "o que há, e já houve em doses mais confortadoras para o homem, são modos de reagir à insatisfação que o mundo nos causa: pela religião, aceitando os desígnios da providencia e remetendo o mundo sem falhas para o além-morte" (PERRONE-MOISÉS, 1990, p. 103). Entretanto, a insatisfação, a certeza de que o mundo não basta, continua no espírito humano, que tentará suprir essa falta secular de outras formas. Uma delas é a arte, já que ela transcende o cotidiano, e configura-se como a linguagem do inefável, inaugurando uma outra realidade, como quer a religião.

Segundo Vahanian (1968), na religiosidade moderna existe uma fidelidade e uma submissão maior do homem para com Deus, porém, esses sentimentos baseiam-se no próprio homem, e não em Deus. Na era pós-cristã, o homem é a medida de todas as coisas. O que orienta os dogmas e preceitos religiosos modernos é a confiança depositada na bondade e na capacidade humana. Cabe ao homem moderno, portanto, buscar na figura de Jesus Cristo o sentido de sua religiosidade, e essa busca, segundo Hamilton (1968), se dá de duas formas: a primeira seria o cristão descobrir Cristo sob os disfarces do mundo, ao realizar essa busca, consequentemente o homem descobriria a si próprio. A outra consiste no homem empenhar-se em se tornar Jesus no mundo e para o mundo, em que se vê um homem se transformando em redentor para os homens.

A leitura que a religiosidade moderna faz da figura de Jesus, entretanto, diverge da defendida pela cristologia patrística ${ }^{3}$ ortodoxa, que, segundo Van Buren, não fez justiça à humanidade de Jesus de Nazaré, quando despreza sua compaixão, seu interesse nos assuntos dos homens e sua relação com outros homens. Por conseguinte, os teólogos modernos se sustentam nestas características de Jesus para proliferar a adoração da sua verdadeira humanidade. Van Buren defende que Cristo foi envolvido nos interesses humanos involuntariamente, ele foi um ser humano, nada "mais do que um homem" (BUREN apud

\footnotetext{
3Visão teológica que os "pais" (padres) da Igreja tinham acerca do Cristianismo, que fundamentou todo o pensamento cristão, assim como influenciou os moldes da cultura ocidental.
} 
BENT, 1968, p. 11).

Vários dos conceitos do Movimento da Morte de Deus convergem para a perspectiva da religiosidade moderna localizada nas obras de Saramago, como por exemplo, sua concepção sobre Deus, que dialoga com as definições de Thomas J. J. Altizer sobre a personagem, uma vez que, ao lermos algumas definições de Deus feitas pelo teórico, temos a impressão de estar diante de uma obra saramaguiana: “O Deus primordial, totalmente outro, transcendente, absoluto, opressivo, alheio, estranho e onipotente morreu em Jesus Cristo" (ALTIZER apud BENT, 1968, p.270). Saramago também defende essa morte de Deus em Jesus Cristo, pois tudo aquilo que procuramos em Deus encontramos em seu filho. Para Saramago, assim como para o Movimento da Morte de Deus, Deus é desnecessário.

Para finalizar, é importante destacarmos este perfil cada vez mais humano de Deus. Hoje, assistimos a um processo de multiplicação das religiões, e o conceito de Deus adotado por cada uma delas é potencialmente mais autônomo e peculiar, para que essa entidade se adapte às suas realidades e exigências, como Vahanian defende:

Alguns destes conceitos são perfeitamente fantásticos. [...] Todos esses conceitos [...] são antropomórficos e tem todos origem na imaginação inflacionária de sentimentalismo. Mas os homens adoram o Deus que merecem. Os homens criam Deus à sua imagem. As suas concepções de Deus só representam uma hipertrofia da compreensão de si mesmos e, às vezes, uma sanção farisaica ou moralista das suas aspirações. [...] Deus acaba por ser apenas o homem ideal (VAHANIAN, apud BENT, 1968, p.33).

Chegamos ao ponto central desta discussão, pois o que Vahanian define acima é o alicerce da Teologia Humanista de Saramago. O que o escritor português constrói ao longo do conjunto de sua obra é apenas isso, um Deus humano e um homem Deus, a perfeição humana é representada através do Jesus Cristo de seu Evangelho Segundo Jesus Cristo. Ele reconhece a tendência do ser humano a uma forma de divindade qualquer, mas rejeita a concretude deste Deus, que existe apenas na cabeça e na vontade do homem. A prova disso é a transformação e a adequação constante e evolutiva do aspecto paternal de um ser supremo, que se adapta às vontades e às necessidades de quem necessita ser orientado constantemente.

\section{CONSIDERAÇÕES FINAIS}

Ao chegarmos ao final deste artigo, uma pergunta insiste em se impor: é, afinal, possível um diálogo entre Religião, Filosofia e Literatura?

A resposta a que chegamos é que essa conversa não só é possível, como viável, já que ambos os campos se entrelaçam. De forma bem didática, a Filosofia pretende tratar do comportamento, das relações humanas; a Religião, por sua vez, intenta suprir o desconhecido, oportunizando uma possibilidade de explicar aquilo que ainda não se conhece; e a Literatura, por fim, pretende tudo isso: tratar do inefável, do pensamento e comportamento humano, da natureza, do exato e do inexato, ao criar mundos e possibilidades que transcendem a razão comum ou mesmo a história da humanidade. Ela vem não apenas propor a história do que poderia ter sido, mas revelar também aquilo que ficou oculto.

A remitologização realizada por Saramago com os textos bíblicos funciona como base para uma finalidade muito maior: a humanização dos episódios e das personagens arquiconhecidas pelo discurso religioso judaico-cristão. 
Muito ainda há que se estudar e investigar a respeito da representação que Saramago faz da religiosidade moderna em suas obras. Entretanto, o teor do trabalho nos fez concentrar nossas atenções nos aspectos mais relevantes. A importância da reflexão que o autor sugere é inquestionável, e, apesar de acrescentar seu tom de ironia ácida, oriundo de seu ateísmo, Saramago não deixa de despertar a atenção do leitor para uma meditação mais aprofundada acerca daquilo que sempre aceitou como verdade imutável.

Partindo da afirmação de Fernando Pessoa de que "a literatura é uma confissão de que a vida não basta", podemos inferir que Saramago contribui sobremodo com esse aspecto da literatura, ao fundar um universo fictício que dialoga com o que há de mais transcendente na vivência humana, fazendo com que relacionemos as indagações presentes nas obras com o nosso próprio universo cultural e religioso. O homem criou a religião para suprir a falta ontológica que marca a insuficiência da vida, e a literatura, que sempre aponta para o que falta no mundo e em nós, uma vez que nasce da vivência da falta e da aspiração à completude, auxilia na compreensão desse mundo religioso.

\section{REFERÊNCIAS}

ARIAS, Juan. Jesus: esse grande desconhecido. Rio de Janeiro: Objetiva, 2001.

BENT, Charles. Linha de Risco: O Movimento da Morte de Deus. Rio de Janeiro, RJ: Moraes Editores, 1968.

BLOCH, Marc Leopold Benjamin. Apologia da história, ou, O oficio do historiador. Rio de Janeiro: Jorge Zahar Ed, 2001.

CASSIRER, Ernst. Ensaio sobre o homem; introdução a uma filosofia da cultura humana. São Paulo: Martins Fontes, 1994.

CRESPI, Franco. A Experiência religiosa na pós-modernidade. Bauru, SP: EDUSC, 1999.

JOHNSON, Paul. Jesus: Uma biografia de Jesus Cristo para o século XXI.Rio de Janeiro: Nova Fronteira, 2001.

KOTHE, Flávio R. A Alegoria. São Paulo: Ática, 1986.

MAGALHÃES, Antonio. Deus no espelho das palavras: Teologia e Literatura em diálogo. São Paulo: Paulinas, 2000.

PERRONE-MOISÉS, Leyla. A criação do texto literário. In: Flores na escrivaninha. São Paulo: Companhia das Letras, 1990.

SARAMAGO, José. O Evangelho segundo Jesus Cristo. São Paulo: Companhia de Bolso, 2005. SYLVESTRE, Fernanda Aquino. Diálogos entre a ficção e a história: o mito bíblico revisitado em Caim, de José Saramago. Revista Alere. Ed. no 4. Tangará da Serra, 2014.

ZUURMOND, Rochus. Procurais o Jesus Histórico?Belo Horizonte: Edições Loyola, 1994. 